\title{
LIVING VALUES EDUCATION DAN IMPLIKASINYA BAGI PENDIDIKAN AGAMA KRISTEN
}

\author{
Karlito Dias Markes \\ Sekolah Tinggi Teologi Injili Setia Siau \\ kmarkes@sttissiau.ac.id
}

Abstract: $\quad$ Education is a process of inheriting life values that serve as a guideline as well as a foundation for character development. Education must be a conscious and planned process and oriented to contextual life values. Living Values Education is one of the patterns education based on life values is deemed sufficiently relevant to Christian Education as a learning process about the living values of Christianity. The Bible explicitly records that the life, teachings and role model of the Lord Jesus have practiced the Living Values Education as a pattern of education. This research was conducted using the Literature Review method, through literature obtained both manually and also through an electronic data base such as Google and Google Scholer. From the literature analysis conducted, this study found three principles as the basis for character development through The Christian Living Values Education . First, the values of human life with God. Second, the values of human life with others. And third, the values of human life by itself. All three values of life have the same substance, namely: love with heart, soul and mind. The hope of this research is that Christian religious educators are held on the values of life centered on Christ.

Keywords: $\quad$ Living Values Education, implication, Christian Religious Education.

\begin{abstract}
Abstrak: $\quad$ Pendidikan merupakan proses pewarisan nilai-nilai hidup yang menjadi pedoman sekaligus landasan pengembangan karakter. Pendidikan harus berproses secara sadar dan terencana serta berorientasi pada nilai-nilai hidup yang kontekstual. Living Values Education merupakan salah satu pola pendidikan berbasis nilai-nilai hidup dipandang cukup relevan dengan Pendidikan Agama Kristen yang adalah pendidikan berbasis nilai-nilai hidup kekristenan. Secara eksplisit Alkitab mencatat bahwa sesungguhnya hidup, ajaran dan teladan Tuhan Yesus sudah mempraktekkan pola pendidikan Living Values Education. Penelitian ini dilakukan dengan metode Literatur Review yakni, melalui literatur yang diperoleh baik secara manual yakni buku-buku maupun artikel-artikel melalui elektronik data base seperti google maupun google scholer. Dari anilisis literatur yang dilakukan maka penelitian ini menemukan tiga hal prinsip sebagai dasar pengembangan karakter melalui The Christian Living Values Education. Pertama, Nilai-nilai hidup mansia dengan Tuhan. Kedua, nilai-nilai hidup manusia dengan sesama. Dan ketiga, nilai-nilai hidup manusia dengan dirinya sendiri. Ketiga nilai-nilai hidup ini memiliki substansi yang sama yaitu: mengasihi dengan hati, jiwa dan akal budi. Harapan dari penelitian ini ialah pendidik Agama Kristen diselenggarakan pada nilai-nilai hidup yang berpusat pada Kristus (The Living Values of Christ Center).

Kata Kunci: Living Values Education, Implikasi, Pendidikan Agama Kristen (PAK)
\end{abstract}




\section{PENDAHULUAN}

Pendidikan sebagai proses pewarisan nilai-nilai hidup yang bermanfaat bagi kehidupan dalam bentuk pengetahuan, penghayatan dan perilaku. Nilai-nilai yang diperoleh melalui proses pendidikan, diharapkan dapat menjadi pedoman hidup sehingga membentuk karakter sosial yang bernilai tinggi. Berkenaan dengan hal tersebut maka proses pendidikan harusnya dikembangkan dalam budaya yang bernilai tinggi agar peserta didik dapat bertumbuh menjadi pribadi yang berkarakter dan berbudaya di tengah-tengah kehidupan bermasyarakat. Undang-Undang No. 20 Tahun 2003 tentang Sistem Pendidikan Nasional. Hal ini berarti pendidikan harus berlansung dalam suasana sadar dan terencana serta berorientasi pada pengembangan potensi spiritual dan akhlak peserta didik yang di dalamnya terkandung nilai-nilai hidup dalam kehidupan bermasayarakat.

John Dewey yang dikutip Arthur bahwa, Pendidikan sebagai rekonstruksi atau reorganisasi pengalaman yang menambah arti pengalaman dan tingkat kemampuan yang mengarah kepada pengalaman-pengalaman berikutnya. ${ }^{1}$ Dalam hal ini pengalaman masa lalu hanya bersifat data yang digunakan untuk menjelaskan atau memperbaiki aktifitas masa yang akan datang. Iris V. Cully menggunakan istilah Pendidikan partisipasi sebagai pendidikan yang berpusat pada kehidupan. ${ }^{2}$ Searah dengan pandangan tersebut, Marc Belth mendefinisikan pendidikan sebagai suatu usaha untuk meningkatkan kapasitas (pribadi) yang unik yang berdasarkan pada pengalaman-pengalaman yang telah dilalui. ${ }^{3}$ Itu berarti pendidikan adalah proses rekonstruksi nilai-nilai hidup yang terkandung dalam 185.

1 Timothy Arthur, Systematic Religious Education (Birmingham: Religious Education Press, 1987),

2 Iris V. Cully, Dinamika Pendidikan Kristen (Jakarta: BPK Gunung Mulia, 2009), 109.

${ }^{3}$ Arthur, Systematic Religious Education, 185. 
pengalaman peserta didik baik secara pribadi maupun dalam masyarakat. Junihot Simanjuntak menggunakan konsep pendidikan sebagai transformasi pengetahuan dan nilai-nilai antar generasi. ${ }^{4}$ Pendapat ini pun terkandung makna pendidikan sebagai proses pewarisan nilai-nilai kehidupan.

Dari penjelasan tersebut penulis berpendapat bahwa pendidikan adalah proses pewarisan nilai yang berbasis living values. Untuk mewujudkan nilai-nilai kehidupan yang berkarakter kuat bagi peserta didik maka diperlukan dua hal penting. Pertama, pendidikan diarahkan kepada proses pengembangan kepribadian yang utuh. Kedua, penyelenggaraan pendidikan lebih memperhatikan konteks peserta didik sebagai objek sekaligus subjek pembelajaran.

Pendidikan yang baik adalah pendidikan yang diarahkan kepada tingkatan kemampuan peserta didik melalui pertimbangan kepribadian, sosial dan kebudayaan peserta didik. Searah dengan pendapat tersebut, Langgulung yang dikutip oleh Purwanto mengungkapkan bahwa:

Pada prinsipnya pendidikan dapat dilihat dari dua sudut pandang: individu dan masyarakat. Dilihat dari sudut pandang individu, pendidikan merupakan usaha untuk membimbing dan menghubungkan potensi individu. Sementara dari sudut pandang kemasyarakatan, pendidikan merupakan usaha pewarisan nilai-nilai budaya dari generasi tua kepada generasi muda, agar nilai-nilai budaya tersebut tetap terpelihara. ${ }^{5}$

Dalam hal ini pendidikan dipandang dalam dua kepentingan yakni: pengembangan potensi individu dan pewarisan nilai-nilai kebudayaan. Artinya, pengembangan nilai-nilai sosial kebudayaan, letaknya pada bagaimana proses pengembangan diri setiap individu yang ada dalam komunitas sosial tersebut. Proses pengembangan inilah yang disebut Living Values Education. Dalam artian

4 Junihot Simanjuntak, Filsafat Pendidikan Dan Pendidikan Kristen (Yogyakarta: ANDI, 2018), 21.

${ }^{5}$ Purwanto M. Ngalim, Psikologi Pendidikan (Bandung: Rosdakarya, 1990), 137. 
bahwa jika pendidikan diarahkan kepada pengembangan nilai-nilai hidup sebagai keyakinan seseorang maka karakter orang tersebut akan terbangun. Selanjutnya jika karakter seseorang terbangun maka nilai-nilai hidup orang tersebut tetap terpelihara pula. Dari proposisi ini maka tugas utama bagi seorang pendidik ialah melibatkan peserta didik secara aktif untuk mengembangkan nilai-nilai hidup yang dimilikinya serta mampu mengimplementasikan dalam kehidupan secara pribadi maupun dalam kehidupan bermasyarakat.

Demikian halnya Pendidikan Agama Kristen sebagai wadah pembelajaran dan pembinaan karakter Kristen diharapkan dapat mengembangkan karakter umat Kristen agar dapat bertumbuh menjadi pribadi yang berkarakter Kristus. Pendidikan Agama Kristen bertujuan untuk mengajar pengikut Kristus agar bertumbuh menjadi pribadi yang beriman kepada Kristus serta mewarisi nilai-nilai iman yang luhur sebagai the living values.

Pendidikan Agama Kristen dipahami sebagai pendidikan iman sekaligus pendidikan karakter. Pembelajaran ini mencakup prinsip-prinsip kehidupan rohani yang berpusat pada nilai-nilai hidup yang terkandung dalam hidup, ajaran dan teladan Kristus (Christ center education). Dalam hal ini pendidikan agama Kristen memiliki hubungan yang sangat signifikan dengan karakter walaupun hakikat Pendidikan Agama Kristen itu jauh lebih luas dari sekedar karakter. Searah dengan pemahaman tersebut, Nuhamara mengemukakan, "pendidikan agama kristen sesungguhnya lebih luas dari sekedar membangun karakter Kristiani, namun karakter Kristiani sangat esensial dalam PAK karena iman tanpa perbuatan adalah mati." ${ }^{6}$ Sijabat menjelaskan bahwa "Karakter juga terbentuk Jaffray 16, no. 1 (19 Maret 2018): 93, https://doi.org/10.25278/jj71.v16i1.278. 
melalui hasil belajar terintegrasi dengan faktor genetika individu serta intervensi ilahi dari Tuhan atau dari roh-roh jahat atau iblis." Dalam hal ini Sijabat lebih menekankan pada proses terbentuknya karakter yang tentu tidak telepas dari tata nilai yang berlaku baik yang bersifat Ilahi dalam kaitan dengan Tuhan maupun bersifat insani dalam kaitan dengan diri peserta didik maupun lingkungan masyarakat. Dari kedua pendapat tersebut, penulis berpendapat bahwa apabila Pendidikan Agama Kristen dan pendidikan karakter diselenggarakan secara terintegrasi maka peserta didik akan mengalami pertumbuhan yang utuh sebagaimana yang dikemukakan Paulus dalam Efesus 4: 15.

Jadi melalui pendidikan Agama Kristen yang berbasis nilai-nilai kehidupan keimanan orang percaya diaktualisasikan melalui praktek hidup yang terpuji dan bernilai bagi sesama dengan tujuan agar hidup yang berpusat kepada Kristus harus juga mencerminkan nilai-nilai kekristenan yang dihidupi the Christian living values). Inilah yang dapat menghantar peserta didik menjadi pribadi yang berkarakter Kristus.

Salah satu perubahan hidup yang diharapkan dari proses Pendidikan Agama Kristen ialah agar peserta didik dapat hidup berpadanan dengan Karakter Kristus. Karakter berasal dari bahasa Yunani, Charassein, yang artinya mengukir. Kata ini diadopsi dari para seniman dalam usaha mengukir batu-batu yang keras menjadi sesuatu yang bernilai tinggi. Dari situlah kemudian istilah ini berkembang menjadi pengertian karakter yang dipahami sebagai tanda khusus

${ }^{7}$ Binsen Samuel Sidjabat, "Penguatan Guru PAK Untuk Pendidikan Karakter: Melihat Kontribusi Seri Selamat," Evangelikal: Jurnal Teologi Injili dan Pembinaan Warga Jemaat 3, no. 1 (30 Januari 2019): 30, https://doi.org/10.46445/ejti.v3i1.121. 
atau pola perilaku. ${ }^{8}$ Dari pengertian tersebut, maka ada dua makna yang terkandung di dalam pengertian karakter. Pertama, karakter adalah suatu pola yang dihasilkan melalui sebuah proses. Ia tidak ada dengan sendirinya, melainkan ia diproses melalui sebuah karya. Kedua, karakter adalah nilai itu sendiri. Dalam makna ini, karakter dilihat sebagai nilai yang dihasilkan melalui sebuah proses pendidikan. Menurut Kamus Lengkap Bahasa Indonesia, "Karakter adalah sifatsifat kejiwaan, akhlak atau budi pekerti yang menjadi ciri khas seseorang."9 Artinya karakter merupakan dimensi kejiwaan dan budi pekerti yang menjadi ciri khas setiap individu. Dalam hal ini, karakter dipahami sebagai akhlak yang menjiwai seseorang sehingga menjadi ciri khas oarang tersebut. Akhlak tersebut bisa berupa nilai-nilai hidup yang diyakini serta membentuk jati diri orang tersebut.

Ironisnya, pengembangan pendidikan saat ini telah mengalami pergeseran makna. Maksud dari penulis ialah pendidikan yang seharusnya berorientasi pada pengembangan kepribadian dan karakter yang utuh dan bermutu telah digeser kepada hal-hal yang tidak substantif dari proses pendidikan itu sendiri. Maknamakna substantif dari sebuah proses pendidikan digeser oleh makna-makna prosedural dan administratif. Hal ini searah dengan pendapat Edi Subkhan yang mengatakan bahwa:

Sekolah menjadi mesin cuci otak modern untuk melunturkaan otentisitas kedirian kita, melucuti paham tata nilai budaya lokal untuk kemudian diajari pengetahuan modern yang dianggap berguna bagi kita tetapi justru menggilas karakter dan jati diri kita. ${ }^{10}$

8 Kokom Komalasari dan Didin Saripudin, Pendidikan Karakter: Konsep Dan Aplikasi Living Values Education (Bandung: Refika Aditama, 2017), 2.

${ }^{9}$ N N, Kamus Lengkap Bahasa Indonesia (Jakarta: Grafindo, 2017), 337.

${ }^{10}$ Edi Subkhan, Pendidikan Kritis: Kritik Atas Praksis Neo-Liberalisme dan Standarisasi Pendidikan (Yogyakarta: Ar-Ruzz Media, 2016), 30. 
Menurut penulis, pendidikan seharusnya membawah pencerahan bagi pengembangan kepribadian peserta diri untuk mengenal karakter dan jati dirinya serta mempertahankannya terhadap pengaruh modernisasi dan globalisasi yang kuat. Menurut Megawangi, "Ukuran keberhasilan dalam peningkatan mutu pendidikan justru disederhanakan pada variable yang sangat kasat mata dengan mereduksi jumlah melek huruf, jumlah lulusan, ketersediaan fasilitas belajar dan angka partisipasi sekolah."11 Demikian juga dalam hal peningkatan penghayatan moral dan keimanan cenderung disederhanakan dalam tataran pembangunan fisik rumah ibadah dan jumlah kehadiran jemaat dalam beribadah. Hal tersebut mengakibatkan terjadinya praktek pendidikan yang kurang memberi perhatian pada nilai yang tertinggi dibalik kuantitas dan kalkulasi secara kasat mata. Demikian juga jati diri keimanan serta integritas yang didalamnya sikap jujur, budaya malu, keramahtamahan dan sifat pengabdian cenderung dipahami dalam ranah teoritis semata ketimbang sebagai praktek kehidupan nyata dari sebuah hasil internalisasi nilai.

Dalam konteks Pendidikan Agama Kristen, penyelenggaraan pendidikan hanya berorientasi pada tuntutan administrasi dan kurikulum semata. Akibatnya karakter Kristus yang diharapkan menjadi the living values peserta didik masih jauh dari harapan itu sendiri. Hal ini dapat kita lihat dalam perkembangan perilaku peserta didik pada umumnya. Fenomena yang terjadi dalam lingkungan masyarakat masa kini, nilai-nilai sosial, budaya dan agama kian semakin tergerus oleh gaya dan pola pergaulan generasi muda cenderung dipengaruhi oleh perkembangan teknologi yang semakin canggih. Pola komunikasi dan informasi

11 Ratna Megawangi, Semua Berakar Pada Karakter (Jakarta: Lembaga Literatur FE UI, 2007). 
yang benar-benar terbuka secara bebas dan luas memengaruhi pola pergaulan anak muda yang dapat dikatakan "bebas nilai". Sedangkan nilai-nilai hidup beragama serta sosial budaya semakin ditinggalkan. Demikian juga Tawuran, pornografi, pornoaksi, bullying dan berbagai bentuk kenakalan remaja sudah dianggap sebagai bagian yang normal dalam perkembangan kepribadian mereka. Keadaan ini tentu menjadi tanggung jawab bersama antara orang tua, gereja dan guru bahkan semua stakeholders pendidikan untuk menanamkan nilai-nilai hidup keKristenan agar kehidupan generasi ini dikembalikan kepada karakter Kristus. Berkenaan dengan pendidikan karakter Kristen, Hartono menjelaskan bahwasannya "pendidikan karakter kristiani bukan sekedar memusatkan diri pada perkembangan sisi manusiawi semata, melainkan memberi jiwa dalam pendidikan itu sebagai pendidikan religius". ${ }^{12}$ Dalam hal ini, Wolterstorff menegaskan bahwa "Pendidikan Karakter Kristen harus mendidik untuk kehidupan seutuhnya dari setiap pribadi." ${ }^{13}$ Maksudnya pendidikan kristen diarahkan kepada keutuhan pribadi peserta didik sebagai objek sekaligus subjek dari proses pendidikan.

Berdasarkan uraian di atas, penulis melakukan penelitian ini dengan tujuan untuk mengkaji implikasi Pendidikan Agama Kristen yang berorientasi pada pengembangan karakter Kristen yang didasarkan pada pola pengembangan living values education. Adapun harapan penulis ialah penelitian ini dapat bermanfaat bagi pengembangan Pendidikan Agama yang berpusat pada karakter Kristus sebagai the Christian living values

\section{METODE}

12 Handreas Hartono, "Membentuk Karakter Kristen Pada Anak Keluarga Kristen," Kurios 2, no. 1 (11 Februari 2018): 62, https://doi.org/10.30995/kur.v2i1.22.

13 Nicholas P. Wolterstorff, Mendidik Untuk Kehidupan (Surabaya: Momentum, 2010), 13. 
Penelitian ini dilakukan dengan pendekatan Literatur review yang mana penulis mengelaborasi beberapa literatur yang berkaitan dengan topik pendidikan agama kristen dan Pendidik karakter yang berorientasi pada Living Values Education serta menganalisis guna merumuskan suatu formulasi pendidikan karakter kristiani sebagai acuan penyelenggaraan pendidikan Agama Kristen.

Adapun analisis dilakukan dengan bersumber pada beberapa literatur yang diperoleh dari Google Scholar maupun Google. Literatur tersebut dianalisis dengan proses penelaahan yang mendalam kemudian dibandingkan serta diuraikan secara sistematis untuk dibahas sesuai kaidah ilmiah. Penelitian ini diharapkan memberikan suatu formula baru baik dalam dimensi teologis maupun paedagogis dalam mengembangkan karakter Kristen sebagai The Living Values Education bagi peserta didik sebagai sebuah kesimpulan akhir.

\section{HASIL}

Melalui kajian beberapa literatur yang telah dilakukan penulis, pada bagian ini penulis menguraikan hasil kajian serta melakukan pembahasan dengan tujuan memperoleh konklusi yang komprehensif dari hakekat pengembangan Pendidikan Agama Kristen dengan model living values education. Hasil penelitian ini untuk memberikan pemahaman bahwa pendidikan Kristen adalah hal yang relevan.

Hasil kajian ini akan memberikan pemahaman tentang konsep living values Education yang berpusatkan pada personalitas dan karya dari Yesus Kristus. Kemudian memberikan pemahaman bagaimana pengaruhnya dalam mengembangkan pendidikan Kristen. Hasil dari ini penelitian ini dapat menjadi 
tindaklanjut oleh peneliti selanjutnya guna mendalami nilai-nilai karakter Kristen dalam pembelajaran Pendidikan Agama Kristen.

\section{PEMBAHASAN}

Dalam pembahasan ini akan menuliskan tentang konsep living values education, The Christian Living Values berdasarkan Ajaran dan Teladan Tuhan Yesus dan Implikasinya Bagi Pendidikan Agama Kristen.

\section{Konsep Living Values Education}

Konsep living values education pertama kali merupakan gerakan yang secara resmi dibentuk oleh UNICEF. Arfan Mu'amar mengemukakan hakekat dari gerakan ini ialah pengembangan nilai-nilai dasar kehidupan yang pada mulanya dideklarasikan oleh Brahma Kumaris pada HUT PBB tahun $1995 .^{14}$ Kemudian living values education dikembangkan untuk memperkuat pendidikan karakter yang didasarkan pada nilai-nilai hidup komunitas dimana pendidikan diselenggarakan. Hal ini dipandang penting karena relitas yang dihadapi saat ini, penyelenggaraan pendidikan diselenggarakan secara parsial yakni terfokus pada satu ranah kompetensi semata yakni kognitif. Gerardette mengemukakan bahwa:

Dunia pendidikan saat ini penuh dengan masalah karena berangkat dari konsep yang kurang tepat. Selama ini menurutnya pendidikan lebih terfokus pada Education of mind (mendidik pikiran), lalu membuka hati dan berharap dunia akan berubah. Padahal pendidikan seperti itu tidak mengubah apa-apa. Pendidikan akan berfungsi dengan baik jika dimulai dengan education of heart, lalu membuka pikiran dan hidup akan berubah. Jadi LVE (living Values Education) itu mendidik hati education of heart bukan education of mind. ${ }^{15}$

14 Arfan Mu'amar, "Membangun Kesadaran Nilai Melalui Living Values Education," rumahpendidikan.id, Runah Pendidikan, 23 Januari 2018, http//rumahpendidikan.id/membangun-kesadarannilai-melalui-living-values-education.

15 Gerrad Philips, "Live Membangun Tuhan Dalam Diri," livingvaluesindonesia.org, Living Values Indonesia, 25 Juni 2015, http://livingvaluesindonesia.org/2015/06/lve-membangun-tuhan-dalam-diri/. 
Dunia saat ini diperhadapkan dengan berubahan tata nilai yang berdampak pada karakter setiap orang. Berkenaan dengan hal tersebut, Komalasari \& Saripudin mengemukakan bahwa "perubahan tata nilai kehidupan masyarakat menyebabkan penurunan kualitas karakter.". ${ }^{16}$ Lebih lanjut Harto berpendapat bahwa "menciptakan suasana berbasis nilai dalam proses belajar mengajar amatlah penting untuk eksplorasi optimal dan pengembangan nilai-nilai oleh anak-anak dan generasi muda." ${ }^{17}$ Artinya, kualitas karakter suatu masyarakat sangat bergantung pada tata nilai yang dimilikinya dan tata nilai itu diperoleh melalui proses belajar mengajar yang berkualitas. Dengan demikian pendidikan karakter yang berbasis living values education bermanfaat bagi generasi muda dalam memelihara dan mempertahankan tata nilai yang dimiliki dalam masyarkat di tengah-tengah tantangan modernisasi dan globalisasi.

Berangkat dari pemahaman tersebut, keKristenan merupakan persekutuan orang-orang yang percaya bahwa Yesus Kristus adalah Tuhan dan Juruselamat bagi pribadi mereka maupun bagi dunia ini. Persekutuan ini memiliki tata nilai yang dipahami, diyakini dan dipraktekkan. Tata nilai kehidupan orang Kristen ini didasarkan pada pewahyuan khusus dari Allah melalui Teladan dan ajaran Tuhan Yesus serta Alkitab sebagai Firman Allah. Tata nilai ini perlu diwariskan melalui proses Living Values Education agar tetap terjaga dan terpelihara di tengah perubahan dunia saat ini. Pada kajian ini, penulis lebih menyoroti Pendidikan Agama Kristen sebagai the Christian living values education yang didasarkan 31.

${ }^{16}$ Komalasari dan Saripudin, Pendidikan Karakter: Konsep Dan Aplikasi Living Values Education,

${ }^{17}$ Kasinyo Harto, "Model Pengembangan Pembelajaran Berbasis Living Valued Education (LVE)," Tadrib: Jurnal Pendidikan Agama Islam 4, no. 1 (2 Juli 2018): 1-20, https://doi.org/10.19109/Tadrib.v4i1.1873. 
pada teladan dan ajaran Yesus sebagaimana yang disaksikan dalam Alkitab sebagai Landasan Fundamental pendidikan Agama Kristen.

\section{The Christian Living Values berdasarkan Ajaran dan Teladan Tuhan Yesus}

Yesus Kristus adalah Guru Agung yang model pembelajaran-Nya menjadi model pendidikan karakter Kristen. Pribadi dan pengalaman Yesus menjadi model bagi proses pendidikan dan pembelajaran karakter Kristen. Clement dari Alexandria sebagaimana yang dikutip oleh Simon P. Wood, mengemukakan bahwa Yesus sebagai seorang guru IA menjelaskan dan menyatakan ajarannya melalui pembelajaran, tapi sebagai pendidik, IA sendiri mempraktekkan apa yang diajarkan-Nya. ${ }^{18}$ Dalam pelayananNya Yesus melakukan beberapa trasformasi pendidikan yang tadinya berpusat kepada Sinagoge atau Bait Allah, menjadi pendidikan yang berbasis pengalaman peserta didik (Students center learning). Ia memulai pengajaranNya dengan pengalaman yang dimiliki peserta didik dimana peserta didik dituntun untuk mengenal dirinya sebagai manusia berdosa yang membutuhkan anugrah keselamatan. Peserta didikan tidak hanya dituntut memenuhi segala hukum Taurat tanpa memahami diri mereka sebagai objek keselamatan. Model ini kemudian diadopsi menjadi model pembelajaran humanistik dimana keberhasilan proses belajar terletak pada bagaimana peserta didik dapat memahami lingkungan dan dirinya sendiri. Pengajaran Yesus dalam Injil Matius 5-7 merupakan bentuk pendidikan karakter yang berangkat dari pemahaman, pengalaman dan lingkungan pendengar. Hal ini merupakan bagian dari proses living values education, dimana nilai-nilai hidup yang dimiliki peserta

18 Simon P. Wood, Christ The Educator Transformation (New York: Father of The Church, t.t.), 54. 
didik menjadi acuan untuk melaksanakan proses pembelajaran. Berikut adalah bentuk-bentuk pembelajaran living values education yang dipraktekkan Yesus dalam pelayananNya.

\section{Ajaran Yesus Memberikan Perspektif Baru}

Secara umum Pendidikan Agama Kristen dalam Perjanjian Baru diawali dengan ajaran dan teladan hidup Tuhan Yesus. Hope S. Antone mengemukakan bahwa "ketika Yesus hidup dan mengajar secara fisik di dunia, pendidikan menurut cara Yesus berpusat pada kemunculan kerajaan Allah." ${ }^{, 19}$ Tentu kerajaan yang Yesus maksudkan bukan dalam perspektif politis tetapi dalam perspektif rohani. Ini adalah bentuk perspektif baru dalam hal penanaman nilai-nilai hidup berkenaan dengan kehidupan kekal.

Demikian juga ketika mengajar dan membimbing murid-murid-Nya, Yesus melihat setiap murid secara utuh. Yesus tidak hanya melihat kemampuan mereka pada saat itu semata, tetapi juga memiliki gambaran yang utuh tentang hidup dan masa depan setiap murid dengan perspektif yang baru. Misalnya, pandangan Yesus tentang Simon yang memiliki sifat impulsif, radikal dan tidak konsisten tersimpan watak yang berani dan teguh. Maka Yesus memberi nama Petrus (Batu karang). Demikian juga dalam diri Yohanes yang tidak mengenal kasihan ("anak guruh"), tersimpan watak yang dapat mengerti perasaan orang lain dan penuh dengan kasih bahkan mendapat sebutan "murid yang dikasihi". Ia dapat melihat kenajisan diri seorang Farisi yang sombong atau seorang wanita hina yang mungkin tidak terlihat oleh orang-orang di sekitarnya. Orang melihat Zakeus hanya sebagai seorang Yahudi yang kerdil dan penuh dengan ketidakjujuran,

${ }^{19}$ Hope S. Antone, Pendidikan Kristen Kontekstual (Jakarta: BPK Gunung Mulia, 2010), 19. 
tetapi Yesus melihat dalam dirinya tersembunyi sifat murah hati yang luar biasa. Demikian juga Matius seorang pemungut cukai yang penuh dengan perilaku korup tetapi Yesus melihat dari perspektif yang berbeda bahwasannya seorang Matius kelak menjadi rasul yang dipakaiNya untuk memberitakan Injil Kristus bagi bangsa-bangsa lain.

Dari penjelasan tersebut, maka pendidikan karakter harus memberikan perspektif yang baru dalam diri setiap peserta didik. Perspektif tersebut tentu diperoleh melalui pengenalan yang utuh dari seorang pendidik terhadap peserta didiknya. Dalam hal ini, dibutuhkan kemampuan visioner dari seorang pendidik untuk melihat keberadaan peserta didik dari perspektif yang lain dalam mengembangkan kompetensi pribadinya sebagai the living values yang baru baginya.

\section{Yesus Mengejawantahkan Ajarannya Secara Sempurna}

Syarat utama dari living values education ialah nilai-nilai integritas. Tuhan Yesus mengajar dengan Integritas yang tinggi karena ajaran dan kehidupanNya menjadi satu kesatuan yang mengandung nilai-nilai hidup. J. M. Price Mengemukakan, "Yesus adalah penjelmaan kebenaran. Ia berkata “Akulah...Kebenaran" (Yoh. 14:6), apa yang diajarkannya diwujudkanNya seratus persen dalam kehidupan-Nya." 20

Bagi peserta didik, pembelajaran yang konkrit terletak pada hidup dan kehidupan pendidik. Arfan Mu'ammar berpendapat bahwa "Model living values education percaya bahwa nilai tidak diajarkan melainkan ditangkap atau 
dirasakan." ${ }^{21}$ Murid belajar dari contoh yang diberikan oleh pendidiknya. Oleh karena itu, sangat penting bagi tiap pendidik untuk menyadari dan terus menghidupkan nilai pribadi mereka. Dalam hal ini pendidikan karakter yang berbasis pada penanaman nilai hidup pun memerlukan pendidik yang berintegritas tinggi. Integritas itu dapat dilihat dari asosiasi antara ajaran dan teladan hidup pendidik di hadapan peserta didik. Searah dengan pandangan tersebut, Lois E. Lebar mengemukakan bahwa "Kristus Yesus adalah Guru yang ahli, sebab Dia sendiri mengejawantahkan kebenaran itu secara sempurna." 22 Dari penjelasan tersebut maka pengajaran yang berbasis karakter hanya dimungkinkan apabila pendidik mampu mengasosiasikan isi pengajarannya dengan dirinya sendiri sebagaimana secara hakiki dinyatakan Yesus Kristus dalam injil Yohanes 14: 6.

\section{Yesus Benar-Benar Memperhatikan Dialektika Teks Dan Konteks}

Setiap pengajaran Yesus dilatari oleh dua hal yaitu latar belakang teks dan latar belakang dari kehidupan orang-orang Yahudi itu sendiri. Dialektika teks dan konteks pendengar menjadi poin utama yang diperhatikan Tuhan Yesus ketika melakukan pengajaranNya. Peristiwa IA memberi makan lima ribu orang (Mat. 14: 13-21; Mar. 6: 30-44; Luk. 9: 10-17; Yoh. 6: 1-13) menjadi dasar untuk mengajarkan tentang Yesus sebagai Roti Hidup. Demikian pula ketika Yesus berhadapan dengan Imam-imam dan ahli-ahli Taurat, IA selalu mengutip ayatayat kitab Perjanjian Lama sebagai dasar pernyataan dan pengajaranNya. Dengan demikian, Yesus sebagai Guru Agung melakukan pengajaran dengan memperhatikan kondisi pemahaman dan pengalaman peserta didik-Nya bahkan selalu memulai ajaran-Nya berdasarkan nilai-nilai hidup yang diyakini-Nya. Cara 
yang digunakan Yesus sesungguhnya termasuk dalam model living values Education.

\section{Pengajaran Yesus Terarah Kepada Setiap Pendengar Secara Pribadi}

Dalam pengajaran-Nya Yesus senantiasa melibatkan pendengar dari berbagai kalangan seperti: Imam, ahli-ahli Taurat, kaum awam, Pemungut cukai, Nelayan, Petani, kaum marginal, dll. Demikian pula jumlah pendengar yang dihadapi pun berbeda-beda misalnya; ribuan orang (Mat. 14: 13-21), dua belas orang (Mat. 10: 5-15; Mar. 6: 6b-13; Luk. 9: 1-6), dua orang bersaudara Simon Petrus dan Andreas (Mat. 4: 18-19), bahkan terhadap setiap pribadi yang IA jumpai seperti Nikodemus (Yohanes 3) maupun perempuan Samaria (Yoh. 4). Namun setiap pengajaran-Nya terarah kepada setiap pribadi yang mendengarkanNya. Ajaran-Nya bersifat pribadi karena IA tahu dan mengenal benar bahwa masing-masing murid berbeda, masing-masing orang berbeda kubutuhan, masalah dan karakternya sehingga jika pengajaranNya tida mencakup pribadi-pribadi tersebut maka Tujuan pembelajaranNya tidak tercapai.

Sementara itu kita melihat bahwa pola-pola pengajaran Yesus dalam berbagai peristiwa pembelajaran, kita pertama-tama diperhadapkan dengan sebuah fakta bahwa Yesus tidak pernah menggunakan bahasa-bahasa yang meniru-niru (Strereotype) melainkan IA mengajar sebagai orang yang penuh kuasa (Mat. 7: 29), mengajar dengan penuh kejujuran (Mar. 12: 14) sehingga orang banyak yang takjub mendengarkan ajaranNya (Mat. 22: 33). Yesus mengajar tentang apa yang 
Ia telah lakukakan sehingga antara ajaran dan pengalaman hidup itu menjadi satu kesatuan yang tidak terpisahkan.

Dalam pembelajaran pada umumnya kita menjumpai adanya proses internalisasi nilai yang terkandung dalam pengetahuan kepada pribadi peserta didik. Demikian juga dalam berbagai situasi pembelajaran yang dihadapi Yesus Kristus, Ia selalu menghubungkan hal-hal yang ada disekitar pendengar sebagai pengantar kepada kebenaran yang diajarkan dengan harapan pendengar lebih mudah untuk mencerna setiap hal yang diajarkan. Setiap pengajaran harus mengarahkan peserta didik kepada kecintaan akan kebenaran Allah (loving the Truth of God). Oleh karena itu, setiap pengajaran haruslah diajarakan sesuai dengan kehendak Allah agar pemikiran, perasaan, perilaku dan seluruh eksistensi peserta didik menjadi alat kebenaran (band. Rom. 6: 13) dan sebagai persembahan yang hidup, kudus dan yang berkenan kepada Allah.

\section{Implikasi Bagi Pendidikan Agama Kristen}

Pendidikan Agama Kristen dipahami sebagai wadah perjumpaan antara manusia dengan Allah. Sejak kejatuhan manusia dalam dosa (band. Kejadian 3), hubungan manusia dengan Allah telah di-distorsi oleh keberdosaan manusia. Setiap usaha manusia untuk berjumpa dengan Allah selalu mengalami kebuntuan karena kutuk dosa yang dialaminya. Oleh karena itu manusia perlu mengalami perjumpaan pribadi dengan Allah melalui Yesus Kristus untuk memperoleh pendamaian, penebusan dan keselamatan. Hal ini dijelaskan oleh Bhoelke:

Tujuan dari pada penyelenggaraan Pendidikan Agama Kristen ialah memampukan setiap orang agar menjadi sadar akan kasih Allah yang tetap 
mencari, sebagaimana yang dinyatakan dalam Yesus Kristus, dan untuk memberi jawaban terhadap kasih tersebut melalui iman. ${ }^{23}$

Dalam arah itu, maka pendidikan Agama Kristen berusaha mempertemukan manusia dengan Allah sehingga manusia dalam keberadaanya dapat menerima Yesus Kristus sebagai Juruselamat pribadinya. Hal inilah yang menjadi esensi perjumpaan antara manusia dengan Allah. Berkenaan dengan hal tersebut, Homrighausen dan Enklaar menjelaskan demikian:

Bukankah kita semua mengiyakan bahwa pendidikan agama kristen bukan saja perkara ajaran dan pengakuan secara teori, tetapi juga suatu kuasa Ilahi yang seharusnya mempengaruhi dan menguasai seluruh alam perasaan, kehendak dan tingkah laku manusia. ${ }^{24}$

Artinya Pendidikan Agama Kristen perlu diarahkan kepada perjumpaan yang utuh setiap peserta didik dengan Allah agar perubahan hidup yang diharapkan melalui proses perjumpaan ini juga bersifat utuh (holistic).

Pendidikan Agama Kristen adalah pendidikan yang berproses secara Alkitabiah dengan tujuan menanamkan nilai-nilai iman kristen agar peserta didik dapat bertumbuh dalam kedewasaan iman serta hidup berpadanan dengan karakter Kristus disetiap aspek kehidupan. Di sini Alkitab menjadi landasan fundamental penyelenggaraan proses Pendidikan Agama Kristen dan Kristus menjadi pusat pengajaran Pendidikan Agama Kristen (Christ center education). Dengan demikian maka pendidikan Agama Kristen adalah pendidikan yang diselenggarakan berdasarkan pada nilai-nilai hidup yang ada dalam ajaran dan diri Yesus Kristus seperti Kasih, kesucian, kesederhanaan, ketaatan, kesetiaan, kejujuran dan kecintaan kepada kebenaran. Hal-hal tersebut menjadi nilai-nilai

${ }^{23}$ Robert Boehlke, Sejarah Perkembangan Pikiran dan Praktek PAK: dari Plato sampai IG. Loyola (Jakarta: BPK Gunung Mulia, 2006), 536. 1993), 25.

${ }^{24}$ Homrighausen E G dan I.H. Enklaar, Pendidikan Agama Kristen (Jakarta: BPK Gunung Mulia, 
hidup yang diiman baik oleh pendidik maupun peserta didik. Agar nilai-nilai tersebut menjadi standar hidup orang Kristen maka diperlukan formulasi pembelajaran yang berbasis pada living values education.

Firman Tuhan secara eksplisit telah memberikan sebuah formulasi pembelajaran yang penulis sebut the Christian living values education sebagaimana yang diperintahkan Tuhan Yesus sebagai hukum Kasih menurut Matius 22: 37-39. Ada beberapa prinsip nilai-nilai kehidupan berdasarkan hukum kasih tersebut. Pertama, Nilai-nilai perilaku manusia kepada Tuhan. Kedua, nilainilai perilaku manusia kepada sesamanya. Dan ketiga, nilai-nilai perilaku manusia terhadap dirinya sendiri. Ketiga nilai hidup ini memiliki substansi yang sama yaitu: mengasihi dengan hati, jiwa dan akal budi. Dengan demikian maka Pendidikan Agama Kristen memiliki peran sebagai the Christian living values education yang bertugas menuntun peserta didik untuk mengenal Allah-nya dalam Yesus Kristus, tetapi sekaligus mengenal dirinya sebagai gambaran Allah (imago Dei) serta hidup seturut peta dan teladan (karakter) Allah yang dinyatakan dalam teladan Yesus Kristus.

\section{KESIMPULAN}

Berdasarkan uraian kajian di atas maka penulis menarik kesimpulan sebagai berikut: 1). living values education merupakan model pembelajaran yang relevan dengan Pendidikan Agama Kristen sebagai pendidikan penanaman nilainilai hidup kristen. 2). Hakekat model pembelajaran living values education sesungguhnya secara praktis sudah diterapkan dalam diri, ajaran dan teladan Tuhan Yesus sebagai Guru Agung. Dalam konteks ini, pola pengajaran Tuhan Yesus senantiasa memberikan perspektif yang baru tetapi didasarkan pada teks 
dan konteks dimana pembelajaran berlangsung. Hal ini terlihat ketika Yesus memulai pengajaran selalu mengutip kitab-kitab Taurat dan Perjanjian Lama untuk menegaskan bahwa hidup, ajaran dan teladan-Nya merupakan penggenapan dari kitab-kitab Taurat dan kitab para nabi. 3). Melalui model pembelajaran living values education, pengembangan karakter peserta didik diarahkan kepada karakter Kristus sebagai pusat pembelajaran iman Kristen. 4). Melalui kajian ini pendidikan agama Kristen diarahkan pada prinsip yang penulis sebut the Christian living values education dengan hukum Kasih menurut Matius 22: 37-39 sebagai landasanya. Dalam hal ini ada tiga prinsip nilai-nilai kehidupan berdasarkan hukum kasih yang perlu diterapkan. Pertama, Nilai-nilai hidup manusia kepada Tuhan. Kedua, nilai-nilai hidup manusia kepada sesamanya. Dan ketiga, nilai-nilai hidup manusia terhadap dirinya sendiri. Ketiga nilai hidup ini memiliki substansi yang sama yaitu: mengasihi dengan hati, jiwa dan akal budi.

\section{DAFTAR PUSTAKA}

Antone, Hope S. Pendidikan Kristen Kontekstual. Jakarta: BPK Gunung Mulia, 2010.

Arthur, Timothy. Systematic Religious Education. Birmingham: Religious Education Press, 1987.

Boehlke, Robert. Sejarah Perkembangan Pikiran dan Praktek PAK: dari Plato sampai IG. Loyola. Jakarta: BPK Gunung Mulia, 2006.

Cully, Iris V. Dinamika Pendidikan Kristen. Jakarta: BPK Gunung Mulia, 2009.

G, Homrighausen E, dan I.H. Enklaar. Pendidikan Agama Kristen. Jakarta: BPK Gunung Mulia, 1993.

Harto, Kasinyo. "Model Pengembangan Pembelajaran Berbasis Living Valued Education (LVE)." Tadrib: Jurnal Pendidikan Agama Islam 4, no. 1 (2 Juli 2018): 1-20. https://doi.org/10.19109/Tadrib.v4i1.1873.

Hartono, Handreas. "Membentuk Karakter Kristen Pada Anak Keluarga Kristen." $\begin{array}{lllllll}\text { Kurios } & 2, & \text { no. } & 1 & (11 \quad \text { Februari 2018): } 62 .\end{array}$ https://doi.org/10.30995/kur.v2i1.22. 
Komalasari, Kokom, dan Didin Saripudin. Pendidikan Karakter: Konsep Dan Aplikasi Living Values Education. Bandung: Refika Aditama, 2017.

Lebar, Lois E. Education That Is Christian. Malang: Gandum Mas, 2006.

Megawangi, Ratna. Semua Berakar Pada Karakter. Jakarta: Lembaga Literatur FE UI, 2007.

Mu'amar, Arfan. "Membangun Kesadaran Nilai Melalui Living Values Education." Rumahpendidikan.id. Runah Pendidikan, 23 Januari 2018. http//rumahpendidikan.id/membangun-kesadaran-nilai-melalui-livingvalues-education.

N, N. Kamus Lengkap Bahasa Indonesia. Jakarta: Grafindo, 2017.

Ngalim, Purwanto M. Psikologi Pendidikan. Bandung: Rosdakarya, 1990.

Nuhamara, Daniel. "Pengutamaan Dimensi Karakter Dalam Pendidikan Agama Kristen." Jurnal Jaffray 16, no. 1 (19 Maret 2018): 93. https://doi.org/10.25278/jj71.v16i1.278.

Philips, Gerrad. "Live Membangun Tuhan Dalam Diri." Livingvaluesindonesia.org. Living Values Indonesia, 25 Juni 2015. http://livingvaluesindonesia.org/2015/06/lve-membangun-tuhan-dalamdiri/.

Price, J.M. Jesus The Teacher. Bandung: Lembaga Literatur Baptis, 2011.

Sidjabat, Binsen Samuel. "Penguatan Guru PAK Untuk Pendidikan Karakter: Melihat Kontribusi Seri Selamat." Evangelikal: Jurnal Teologi Injili dan Pembinaan Warga Jemaat 3, no. 1 (30 Januari 2019): 30. https://doi.org/10.46445/ejti.v3i1.121.

Simanjuntak, Junihot. Filsafat Pendidikan Dan Pendidikan Kristen. Yogyakarta: ANDI, 2018.

Subkhan, Edi. Pendidikan Kritis: Kritik Atas Praksis Neo-Liberalisme dan Standarisasi Pendidikan. Yogyakarta: Ar-Ruzz Media, 2016.

Wolterstorff, Nicholas P. Mendidik Untuk Kehidupan. Surabaya: Momentum, 2010.

Wood, Simon P. Christ The Educator Transformation. New York: Father of The Church, t.t. 